\title{
Meat Tenderization of Efficiency of Papain, Bromelain and Zingiber officinale on Old Aged Beef Carcass of local Zebu cattle
}

\author{
Endalk Habtu ${ }^{1}$, Berhe Mekonnen ${ }^{1}$, Habtom Kiros ${ }^{1}$, Haben Fesseha ${ }^{2 *}$ and Bayush Getachew ${ }^{1}$ \\ ${ }^{1}$ College of Veterinary Science, Mekele University, P. O. Box 2084, Mekele, Ethiopia \\ ${ }^{2}$ School of Veterinary Medicine, Wolaita Sodo University, P. O. Box 138, Wolaita Sodo, Ethiopia
}

Submission: March 17, 2020; Published: June 25, 2020

*Corresponding author: Haben Fesseha, School of Veterinary Medicine, Wolaita Sodo University, P. O. Box 138, Wolaita Sodo, Ethiopia, tseyon.h@ gmail.com

\begin{abstract}
An experimental study was conducted from December 2018 to April 2019 to develop a method for improving tenderness and overall qualities of old aged beef carcass of local zebu cattle using plant proteolytic enzymes from papain (Carica papaya), bromelain (pineapple) and zingbain (Zingiber officinale) and their tenderizing efficacy were compared based on marinating time related with pH variation at different time interval $(0 \mathrm{hr}, 4 \mathrm{hrs}, 8 \mathrm{hrs}$, and $12 \mathrm{hrs})$. Then, $3 \times 3 \times 3 \mathrm{~cm}$ chunks from Biceps femoris muscles of local zebu cattle $(7$ years age) were marinated with distilled water (control), powdered Carica papaya extract, Zingiber officinale extract and papain for 48 hours at $4{ }^{\circ} \mathrm{C}$ and subjected to various physicochemical, and sensory evaluations. Accordingly, the $\mathrm{pH}$ of the meat was significantly $(\mathrm{p}<0.01)$ changed in all enzyme-treated samples compared to control. However, there was no significant $(p>0.05)$ change in the weight of the meat before and after marination in all enzyme-treated groups. The highest and least weight after cooking was recorded from papain $(36.2 \pm 0.56 \mathrm{gm})$ and zingbain $(30.88 \pm 0.57 \mathrm{gm})$, respectively. The weight of meat after cooking was significantly $(\mathrm{p}=0.0000)$ changed in all three enzyme treated groups. After cooking, significant $\mathrm{pH}$ variation on the meat was observed, with the highest (Zingbain, $0.7 \pm 0.012)$ and least was observed from papain $(0.2 \pm 0.04)$ and bromelain $(0.23 \pm 0.04)$. Improvement in flavor, juiciness, tenderness, and overall acceptability scores were observed in all enzyme-treated samples compared to controls. Thus, it is shown that papain treated meat samples received a higher $(73.7 \%)$ level of customer satisfaction for appearance, flavor, tenderness, and overall acceptability and can be used as an effective alternative for meat tenderization.
\end{abstract}

Keywords: Bromelain; Papain; Proteolytic Enzymes; Tenderization; Zingbain

\section{Introduction}

Meat is the most valuable livestock product and for many people serves as their first-choice source of animal protein. Meat is either consumed as a component of kitchen-style food preparations or as processed meat products. After the slaughter of animals' natural process or rigor mortis shorten muscle protein fibers and results in meat to become tough [1]. In today's world, the food economy has linked to food security concept that has acquired a new approach arising from globalization in the food trade, where Hazard Analysis Critical Control point (HACCP) systems have been introduced to produce safe food [2, 3].

Consumers understand the meat tenderness variability so; production of consistently tender meat is required to retain consumer confidence in quality meat which is competing with other types of meat that do not have toughness problems [4]. Consumer acceptance of meat is strongly influenced by eating quality meat having fresh and processed meat such as color, flavor, juiciness, water holding capacity, cooking losses and texture [5].
The major cause of poor-quality meat and the international market ban was the toughness of meat. An ongoing challenge for the meat industry is the inability to produce high-quality meat having consistent flavor and texture [6]. Texture is the most important meat quality attribute it determines the consumer acceptance and marketability of final products. Texture quality is evaluated by consumers based on the sensory consideration of appearance, tenderness, and juiciness $[7,8]$. Tenderness has been identified as the most important factor affecting consumer satisfaction and perception of taste. Meat quality can be achieved by the application of either chemically or physically and treatment by proteolytic enzymes is one of the popular methods for meat tenderization. Proteolytic enzymes derived from plants, such as papain, bromelain and ficin have been widely used as meat tenderizers in most parts of the world and they are the most important enzymes in several industries with $60 \%$ of the total market share [9]. Papain and bromelain being the two major 
proteases enzymes in the food industry that takes $8 \%$ of market demand [10].

In addition, meat tenderness can be improved using enzymes papain and microbial enzyme [11], electrical stimulation, heat, and pressure [12], ginger extract [13], marination [14], ultrasound [15]. Moreover, papain, ficin, bromelain, Aspergillus oryzae protease and Bacillus subtilis protease recognized as safe for meat tenderization by United States federal agencies and other enzymes such as ginger rhizome have been evaluated for their effect on meat tenderization [16].

Meat tenderness is influenced by the length of the sarcomeres, structural integrity of the myofibrils that influence the actomyosin toughness. Meat from older animals is generally tougher than meat from young animals since old animals have more collagen cross-linking. Even though meat industries are working on production of high-quality meat with consistent tenderness to increase consumer confidence and encourage further purchase of meat products, the problem is not solved effectively [17-19]. Despite easy availability and many useful properties, papain (Carica papaya), bromelain (pineapple) and zingbain (zingiber officinale) have not been exploited by the meat industry due to lack of scientific literature. Hence, the current investigation was undertaken to identify the meat tenderizing efficacy of Carica papaya, pineapples, and zingiber officinal and determine the customer satisfaction level.

\section{Materials and Methods}

\section{Meat Sample Preparation}

Biceps femoris muscles of adult male local Zebu breed (7 years age) were collected within 2-3-hour post-slaughter from a selected retail meat shop in Mekelle city. Then, all meat samples were transported to laboratory for further experimental process and they were packed in low-density polyethylene (LDPE) bags and stored in refrigerator at $4{ }^{\circ} \mathrm{C}$ for 24 hours. After 24-hour chilling, muscles were taken out of refrigerator and cut into small chunks of approximately $3 \mathrm{~cm}^{3}$ size and were randomly grouped for different treatments. Then, the meat samples were divided into 4 (each having 50gram weight) and then marinate the meat for 2:00-3:30hrs with the proteolytic enzymes. Moreover, the parameters $(\mathrm{pH}$, weight (before and after marinated), cooking loss, moisture content and customer satisfaction level were also recorded.

\section{Experimental Protocol and Study design}

In-vitro experimental study was conducted from December 2018 to March 2019 to compare the effectiveness of selected plant extract enzyme from (papaya, pineapple, and zingiber officinale respectively based on different parameters to tough meat of old aged beef, and determine the level of consumer satisfaction during the consumption of treated meat in the four different groups (control, bromelain, papain, and zingbain).

During the experiment, extraction, purification, centrifugation, drying and size reduction of papain, bromelain, and zingbain enzymes were conducted. Moreover, the $\mathrm{pH}$ before and after cooking, yield in (\% and gram), cooking loses in (\% and gram), weight before and after marinating, effect of marinating time on the meat was determined and recorded in the microbiology laboratory. Finally, their effectiveness was determined by the 6 labels of customer satisfaction (Extremely liked, moderately liked, liked, neither like nor dislike, disliked, moderately disliked, and extremely disliked) based on the taste, texture, juiciness, appearance, palatability, softness and attractiveness (Figure 1).
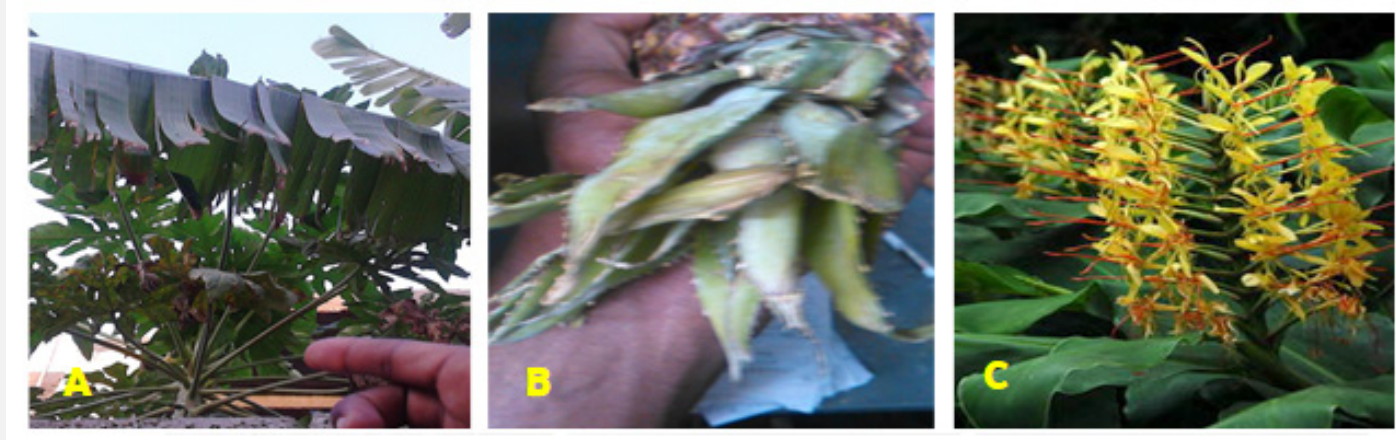

Figure 1: A) Carica papaya, B) Ananas Cosmusous, C) Zingiber officinale.

\section{Plant Collection, Preparation, Storage and Extraction}

\section{Papain (Carica papaya)}

The papaya latex was collected from private owners and papain was extracted from unripe papaya fruit by using the method of [20]. The collected papain extract was kept in sterilized container by adding preservative to avoid the degradation of the enzyme. The papain enzyme powder was prepared by drying the fluid extract for final application. 


\section{Zingbain (Zingiber officinale) and Bromelain (Pineapple)}

Fresh ginger rhizome and pineapple plant (Ananas comosus) from a local market was collected and peeled, cut into smaller pieces by knife (stainless steel) and blended with equal quantity of chilled, distilled water for 1-2 min. Then, put in juice machine, take into orbital shaker to remove the decant and take the supernatant for further processing. Finally, the homogenate was squeezed with fingers through four layers of muslin cloth.

\section{Enzyme treatment and marination}

About $3 \times 3 \times 3 \mathrm{~cm}$ uniform-sized local zebu meat chunks were sprayed with different concentration of powdered papain (Carica papaya), bromelain (pineapple) and zingbain (Zingiber officinale), respectively. After thorough mixing by hand, chunks were placed in polyethylene bags and kept at $4 \pm 1{ }^{\circ} \mathrm{C}$ for 48 hours. Thus, there were four treatments (Table 1). After 48 hours of marination, the $27-\mathrm{cm}^{3}$ meat chunks were washed, drained, and cooked in oven at $75 \pm 1^{\circ} \mathrm{C}$ for $20 \mathrm{~min}$. The cooked samples were evaluated for cooking yield, $\mathrm{pH}$, moisture, shear force values and sensory attributes at different time interval. Raw meat chunks (before cooking) were also subjected to various types of physico-chemical and sensory analysis of meat-based on different parameters.

Table 1: Four Enzyme Treatments.

\begin{tabular}{|c|c|}
\hline $\begin{array}{c}\text { Treatment } \\
\text { Group }\end{array}$ & Treatment Type \\
\hline Control & $30 \mathrm{ml}$ distilled water \\
\hline Bromelain & 50 -gram meat marinated by $30 \mathrm{ml}$ bromelain solution \\
\hline Zingbain & 52 -gram meat marinated by $30 \mathrm{ml}$ zingbain solution \\
\hline Papain & 51-gram meat marinated by 5-gram papain in $30 \mathrm{ml}$ \\
distilled water
\end{tabular}

\section{Estimation of different parameter}

Different formulas were used to estimate different parameters such as weight before and after marinating, weight after cooking, $\mathrm{pH}$ before and after cooked are the measured and recorded. Besides, percentage in weight increased before and after marination, Cooking yield (CY) \%, Cooking lose (CL) /moisture content in $\%$ and Coking lose /gram were also calculated using the standard formula as described below:

a) WIAM in

$\%=\frac{\text { weight after marinated }- \text { weight before marinated }}{\text { weight before marinated }} \times 100$

b) $\quad \mathrm{CY}$ in $\quad \%=\frac{f W}{i W} * 100$

Where fw= final weight after cooked, iw = initial weight after marinated c) CL in gram= weight after marinating - weight after cooked

d) CL in $\%=100 \%$ - cooking yield in $\%$.

Besides, the $\mathrm{pH}$ of the meat sample was taken before marination with all treatment proteolytic enzymes at different time interval (Table 2).

Table 2: $\mathrm{pH}$ value of each sample at the at different time intervals in hours.

\begin{tabular}{|c|c|c|c|c|}
\hline \multirow{2}{*}{$\begin{array}{c}\text { Marinating } \\
\text { Time }\end{array}$} & \multicolumn{4}{|c|}{ pH Value of Each Sample at the given Time Period } \\
\cline { 2 - 5 } & Control $^{1}$ & Bromelain $^{2}$ & Papain $^{3}$ & Zingbain $^{4}$ \\
\hline \multirow{4}{*}{0 hr. } & 5.65 & 6.33 & 6.64 & 5.3 \\
\cline { 2 - 5 } & 5.63 & 6.35 & 6.59 & 5.33 \\
\cline { 2 - 5 } & 5.66 & 6.36 & 6.63 & 5.35 \\
\cline { 2 - 5 } & 5.64 & 6.31 & 6.61 & 5.33 \\
\hline \multirow{4}{*}{4 hrs. } & 5.65 & 6.34 & 6.65 & 5.31 \\
\cline { 2 - 5 } & 5.64 & 6.38 & 6.6 & 5.33 \\
\cline { 2 - 5 } & 5.65 & 6.37 & 6.65 & 5.35 \\
\hline \multirow{4}{*}{8 hrs. } & 5.66 & 6.33 & 6.63 & 5.37 \\
\cline { 2 - 5 } & 5.65 & 6.45 & 6.68 & 5.34 \\
\cline { 2 - 5 } & 5.64 & 6.39 & 6.66 & 5.36 \\
\cline { 2 - 5 } & 5.66 & 6.41 & 6.63 & 5.38 \\
\hline & 5.67 & 6.38 & 6.67 & 5.4 \\
\hline & 5.66 & 6.65 & 6.71 & 5.36 \\
\cline { 2 - 5 } & 5.64 & 6.45 & 6.74 & 5.39 \\
\hline & 5.67 & 6.51 & 6.71 & 5.43 \\
\hline & 5.68 & 6.53 & 6.75 & 5.48 \\
\hline
\end{tabular}

151 -gram meat as control with $30 \mathrm{ml}$ water

250-gram meat marinated by $30 \mathrm{ml}$ bromelain solution

351 -gram meat marinated by 5 -gram papain in $30 \mathrm{ml}$ distilled water

${ }^{4} 52$-gram meat marinated by $30 \mathrm{ml}$ zingbain solution

\section{Data management and Statistical Analysis}

All experiments data were entered to the Microsoft Excel and analyzed by STATA version 13 statistical software package using standard procedures for analysis of variance (ANOVA) and multiple range test to compare the means and determine the effect of treatments were done and $\mathrm{p}$-value $(\mathrm{p}<0.05)$ were considered as statistically significant.

\section{Results and Discussion}

The effect of cooking of after marinating using all proteolytic enzymes were performed after three hours at $60^{\circ} \mathrm{C}$. Change in the given a parameter were observed in all enzyme-treated samples compared to control due to cooking of the marinated meat samples. This might be due to an increase in collagen solubility, sarcoplasmic and myofibrillar protein solubility, and reduction in shear force values (Table 3 ). 
Table 3: Parameter after 3hrs marinating and cooking at $60^{\circ} \mathrm{C}$ for 10 minutes.

\begin{tabular}{|c|c|c|c|c|c|c|c|c|c|c|}
\hline \multirow{2}{*}{ Samples } & \multicolumn{3}{|c|}{ Measured Value (MV) } & \multicolumn{4}{|c|}{ Calculated Value (CV) } & \multicolumn{3}{|c|}{ MV } \\
\hline & WBM/g & WAM/g & WAC/g & WIAM /\% & $\mathrm{CY} / \%$ & CL/\% & $\mathrm{CL} / \mathrm{g}$ & $\mathrm{pH} /{ }^{\mathrm{bc}}$ & $\mathrm{pH} / \mathrm{ac}$ & $\Delta \mathrm{in} \mathrm{pH}$ \\
\hline \multirow{4}{*}{ Control } & 51 & 52.55 & 34.52 & 3.04 & 65.7 & 34.3 & 18.04 & 5.66 & 6.02 & 0.36 \\
\hline & 51 & 52.54 & 34.51 & 3.02 & 65.7 & 34.3 & 18.03 & 5.67 & 6.01 & 0.34 \\
\hline & 49.5 & 50.85 & 32.83 & 2.73 & 65.6 & 34.4 & 18.02 & 5.66 & 6.03 & 0.37 \\
\hline & 50 & 51.56 & 33.75 & 3.12 & 65.5 & 34.5 & 17.81 & 5.71 & 6.22 & 0.31 \\
\hline \multirow{4}{*}{ Bromelain } & 50 & 51.3 & 32.94 & 2.6 & 64.21 & 35.79 & 18.36 & 6.34 & 6.6 & 0.26 \\
\hline & 51 & 52.22 & 34.01 & 2.4 & 65.13 & 34.87 & 18.21 & 6.32 & 6.58 & 0.26 \\
\hline & 49 & 50.3 & 32.4 & 2.65 & 64.4 & 35.6 & 17.9 & 6.33 & 6.56 & 0.23 \\
\hline & 50 & 51.2 & 33.2 & 2.4 & 64.8 & 35.2 & 18.01 & 6.35 & 6.52 & 0.17 \\
\hline \multirow{4}{*}{ Papain } & 51 & 52.2 & 36.13 & 2.35 & 69.21 & 30.79 & 16.07 & 6.48 & 6.7 & 0.22 \\
\hline & 50 & 51.4 & 35.65 & 2.8 & 69.36 & 30.64 & 15.75 & 6.51 & 6.66 & 0.16 \\
\hline & 52 & 53.3 & 36.99 & 2.5 & 69.4 & 30.6 & 16.31 & 6.42 & 6.64 & 0.22 \\
\hline & 51 & 52.32 & 36.05 & 2.6 & 68.9 & 31.1 & 16.27 & 6.44 & 6.58 & 0.14 \\
\hline \multirow{4}{*}{ Zingbain } & 52 & 53.33 & 31.6 & 2.56 & 59.25 & 40.75 & 21.73 & 5.31 & 6.04 & 0.71 \\
\hline & 50 & 51.21 & 31 & 2.42 & 60.5 & 39.5 & 20.23 & 5.33 & 6.02 & 0.7 \\
\hline & 49 & 50.11 & 30.26 & 2.27 & 60.4 & 39.6 & 19.85 & 5.31 & 6.31 & 0.7 \\
\hline & 50 & 51.18 & 30.66 & 2.36 & 59.9 & 40.1 & 20.52 & 5.32 & 6.22 & 0.68 \\
\hline
\end{tabular}

Where WBM $(\mathrm{gm})=$ weight before marinating in gram

WAM $(\mathrm{gm})=$ weight after marinating in gram

WAC $(\mathrm{gm})=$ weight after cooked in gram

WIAM $(\%)=$ weight increased after marinating in percent

CY $(\%)=$ cooking yield in percent (calculated)

$\mathrm{CL}(\%)=$ cooking loses or moisture content in \%

$\mathrm{CL}(\mathrm{gm})=$ cooking loses in gram

$\mathrm{pH} / \mathrm{bc}=\mathrm{pH}$ before cooked

$\mathrm{pH} / \mathrm{ac}=\mathrm{pH}$ after cooked

$\Delta$ in $\mathrm{pH}=$ change in $\mathrm{pH}$ increment

\section{$\mathrm{pH}$ variation of meat due to marination}

The $\mathrm{pH}$ variation of meat (Biceps femoris muscle) of three different types of plant extract at the given interval of time in comparison with the control group were evaluated. Accordingly, there was a significant variation on the meat $\mathrm{pH}$ of groups marinated with plant bromelain ( $\mathrm{p}=0.0003)$, zingbain $(\mathrm{p}=0.0136)$ and papain $(\mathrm{p}=0.0001)$. This finding disagreed with the finding of Naveena et al. [21] that states there was no significant difference in the $\mathrm{pH} 48$ hours after treatments between control and marinated groups. These differences might be due to the concentration level of the extracts. Besides, during the conversion of muscle to meat and acidification of the tissue occurs, resulting in a $\mathrm{pH}$ fall from about 7.0 to 5.5 in normal meat $\mathrm{pH}$ (5.4-5.8), the papain from (4.0 - 9.0), bromelain from (4.0-7) from this finding all treatment group fall under the normal range in agreement with results from Calkins and Sullivan, [22].

According to Ha et al. [23], based on the nature and concentrations of the papain and bromelain; the hydrolysis and the breakdown of the meat connective tissue was also varied among plant extract (Table-2). There were visible changes in the breakdown of the fibrous structure of the muscles at the given interval of time. Thus, the collagens crosslink was fragmented or disintegrated into smaller segments; which can address the challenge described by Koohmaraie and Geesink [4], Chen et al. [17]; which stated that; tenderness is influenced by the length of the sarcomeres, structural integrity of the myofibrils that influence the actomyosin toughness. As a result, meat from older animals is tougher than young animals due to an increase in collagen crosslinking this becomes a challenge for the satisfaction of customers and meat processer industries. From this study there was the observation of higher degree of tenderization and fragmented meat part which was treated by papain, thus have a similar idea of Ashie et al. [11] who described the over-tenderization action of papain to the surface of the meat that leads to undesirable mushy appearance.

The color and shelf-life were very different among the experimental group thus, $50 \mathrm{gm}$ meat marinated by $30 \mathrm{ml}$ papain was mushy and well tender until 48hrs without any form of color change at room temperature. While the $50 \mathrm{gm}$ meat marinated 
by $30 \mathrm{ml}$ bromelain and $30 \mathrm{ml}$ zingbain are also tender and stay for $72 \mathrm{hrs}$ without any color change. However, 50-gram meat marinated by $30 \mathrm{ml}$ distilled water as a control shows color change within $24 \mathrm{hrs}$ and it became brown to black gradually after $48 \mathrm{hrs}$ it shows different smell than the others, this may be associated with

Table 4: $\mathrm{pH}$ variation of meat (biceps femoris muscle) by three extracts. the preservative and antimicrobial action of the plant extracts. $\mathrm{pH}$ was increased from the first marinating time to the next marinating time of the different experimental group, this will help to achieve the meat tenderization rate this condition also reported by Takahashi [24] (Table 4).

\begin{tabular}{|c|c|c|c|c|c|}
\hline \multirow{2}{*}{ Experimental Groups } & \multicolumn{4}{|c|}{ Variation of pH at different Time (Mean \pm Std. Dev.) } \\
\cline { 2 - 6 } & $\mathbf{0 h r}$ & $\mathbf{4 h r s}$ & $\mathbf{8}$ hrs & $\mathbf{1 2}$ hrs \\
\hline Control & $5.65 \pm 0.13$ & $5.65 \pm 0.008$ & $5.66 \pm 0.01$ & $5.66 \pm 0.02$ & 0.3228 \\
\hline Bromelain (30 ppm) & $6.34 \pm 0.022$ & $6.36 \pm 0.02$ & $6.41 \pm 0.03$ & $6.54 \pm 0.08$ & 0.0003 \\
\hline Zingbain (30 ppm) & $5.33 \pm 0.02$ & $5.34 \pm 0.03$ & $5.37 \pm 0.03$ & $5.42 \pm 0.05$ & 0.0136 \\
\hline Papain (30 ppm) & $6.62 \pm 0.02$ & $6.63 \pm 0.02$ & $6.66 \pm 0.02$ & $6.73 \pm 0.02$ & 0.0001 \\
\hline
\end{tabular}

\section{Effect of plant extract on weight change of Biceps femoris muscle}

The effect of plant extracts on the weight change of the Biceps femoris muscle meat sample on the [WBM (gm), WAM (gm), WAC (gm), WIAM (\%), Cooking Yield (\%), Cooking loss (\%), cooking loss (gm), pH before cooked, $\mathrm{pH}$ after cooked and $\Delta$ in $\mathrm{pH}$ increment] were recorded. There was no significant change in weight (gram) before ( $\mathrm{p}=0.5014)$ and after $(\mathrm{p}=0.4551)$ marination of meat in all enzyme treated groups as compared to control one. The weight increased after marinating in (\%) was higher in the control than the other $(3 \pm 0.17)$ this may be due to the osmosis process of distilled water transferred into the meat. The weight increased in papain, bromelain and zingbain was $(2.56 \pm 0.19,2.5 \pm 0.13$ and $2.4 \pm 0.12$ ) respectively.

There were significant changes in weight after cooked the control and the experimental groups thus; $(p=0.0000)$. The better weight gained was recorded from papain $(36.2 \pm 0.56$ gram covering $69.23 \pm 0.23 \%$ of cooking yield and the cooking loss in gram was $16.1 \pm 0.26$ covering $30.8 \pm 0.23 \%$ ), followed by the control (33.9 \pm 0.8 gram after cooked covering $65.62 \pm 0.09 \%$ of cooking yield) and the cooking loss in gram was $18 \pm 0.11$ covering $34.34 \pm$ $0.09 \%$ of cooking loss) and the weight after cooked in bromelain was (33.14 \pm 0.67 gram covering $64.64 \pm 0.4 \%$ cooking yield) and the cooking loss in gram was $18.12 \pm 0.2$ covering $35.36 \pm 0.4 \%$ of cooking loss which have less variation with the control; while the least cooked weight was recorded from zingbain (30.88 \pm 0.57 gram covering $60.02 \pm 0.56 \%$ of cooking yield) and the cooking loss in gram was $20.6 \pm 0.81$ covering $40 \pm 0.56 \%$ of cooking loss this may be due to the acidic nature and proteolytic action of the enzymes as described in Table 5. The increased cooking yield was recorded from papain and inversely proportional to cooking loss like the report of Ketnawa and Rawdkuen [25].

Table 5: Effect of plant extract on weight change of Biceps femoris.

\begin{tabular}{|c|c|c|c|c|c|}
\hline \multirow{2}{*}{ Variables } & \multicolumn{4}{|c|}{ Experimental Groups (Mean +Std. Dev.) } & p-value \\
\cline { 2 - 6 } & Control & Bromelain (30 ppm) & Papain (30 ppm) & Zingbain (30 ppm) \\
\hline WBM (gm) & $50.38 \pm 0.75$ & $50 \pm 0.82$ & $51 \pm 0.82$ & $50.25 \pm 1.26$ & 0.5014 \\
\hline WAM (gm) & $51.88 \pm 0.83$ & $51.26 \pm 0.78$ & $52.3 \pm 0.78$ & $51.46 \pm 1.35$ & 0.4551 \\
\hline WAC (gm) & $33.9 \pm 0.8$ & $33.14 \pm 0.67$ & $36.2 \pm 0.56$ & $30.88 \pm 0.57$ & 0 \\
\hline WIAM (\%) & $3 \pm 0.17$ & $2.5 \pm 0.13$ & $2.56 \pm 0.19$ & $2.4 \pm 0.12$ & 0.0011 \\
\hline Cooking Yield (\%) & $65.62 \pm 0.09$ & $64.64 \pm 0.4$ & $69.23 \pm 0.23$ & $60.02 \pm 0.56$ & 0 \\
\hline Cooking loss (\%) & $34.34 \pm 0.09$ & $35.36 \pm 0.4$ & $30.8 \pm 0.23$ & $40 \pm 0.56$ & 0 \\
\hline Cooking loss (gm) & $18 \pm 0.11$ & $18.12 \pm 0.2$ & $16.1 \pm 0.26$ & $20.6 \pm 0.81$ & 0 \\
\hline pH before cooked & $5.68 \pm 0.024$ & $6.34 \pm 0.013$ & $6.46 \pm 0.04$ & $5.32 \pm 0.009$ & 0 \\
\hline pH after cooked & $6.02 \pm 0.008$ & $6.56 \pm 0.034$ & $6.65 \pm 0.05$ & $6.02 \pm 0.013$ & $0.7 \pm 0.012$ \\
\hline$\Delta$ in pH increment & $0.345 \pm 0.03$ & $0.23 \pm 0.04$ & $0.2 \pm 0.04$ & 0 \\
\hline
\end{tabular}


The $\mathrm{pH}$ of raw and cooked meat samples was measured using a digital pH meter Dzudie et al., [26] with some modifications. About $50 \mathrm{~g}$ of biceps femoris meat sample was homogenized with $30 \mathrm{ml}$ of prepared plant extracts individually for $4 \mathrm{hrs}$ at room temperature and then the $\mathrm{pH}$ value of marinated meat was measured before and after cooked at room temperature. The $\mathrm{pH}$ value of biceps femoris meat samples before cooked, after cooked and change in $\mathrm{pH}$ increment was significant $(\mathrm{p}=0.0000)$. From this finding the higher $\mathrm{pH}$ increment was observed in zingbain $(0.7 \pm 0.012)$ after cooked it becomes the normal range of meat $\mathrm{pH}$. While the least $\mathrm{pH}$ increment was recorded from papain $(0.2 \pm 0.04)$ and bromelains $(0.23 \pm 0.04)$ this may be due to the approximate $\mathrm{pH}$ action around the normal range of the meat $\mathrm{pH}$.

\section{Effect of plant extract on weight change of Biceps femoris muscle}

The effect of plant extracts on the weight change of the Biceps femoris muscle meat sample on the WBM (gm), WAM (gm), WAC (gm), WIAM (\%), Cooking Yield (\%), Cooking loss (\%), cooking loss (gm), $\mathrm{pH}$ before cooked, $\mathrm{pH}$ after cooked and $\Delta$ in $\mathrm{pH}$ increment] were recorded. There was no significant change in weight (gram) before ( $\mathrm{p}=0.5014)$ and after $(\mathrm{p}=0.4551)$ marination of meat in all enzyme treated groups as compared to control one. The weight increased after marinating in (\%) was higher in the control than the other $(3 \pm 0.17)$ this may be due to the osmosis process of distilled water transferred into the meat. The weight increased in papain, bromelain and zingbain was $(2.56 \pm 0.19,2.5 \pm 0.13$ and $2.4 \pm 0.12$ ) respectively.

There were significant changes in weight after cooked the control and the experimental groups thus $(\mathrm{p}=0.0000)$. The better weight gained was recorded from papain $(36.2 \pm 0.56$ gram covering $69.23 \pm 0.23 \%$ of cooking yield and the cooking loss in gram was $16.1 \pm 0.26$ covering $30.8 \pm 0.23 \%$ ), followed by the control (33.9 \pm 0.8 gram after cooked covering $65.62 \pm 0.09 \%$ of cooking yield) and the cooking loss in gram was $18 \pm 0.11$ covering $34.34 \pm$ $0.09 \%$ of cooking loss) and the weight after cooked in bromelain was $(33.14 \pm 0.67$ gram covering $64.64 \pm 0.4 \%$ cooking yield) and the cooking loss in gram was $18.12 \pm 0.2$ covering $35.36 \pm 0.4 \%$ of cooking loss which have less variation with the control; while the least cooked weight was recorded from zingbain (30.88 \pm 0.57 gram covering $60.02 \pm 0.56 \%$ of cooking yield) and the cooking loss in gram was $20.6 \pm 0.81$ covering $40 \pm 0.56 \%$ of cooking loss this may be due to the acidic nature and proteolytic action of the enzymes as described in Table 5. The increased cooking yield was recorded from papain and inversely proportional to cooking loss similar to the report of Ketnawa and Rawdkuen [25].

The $\mathrm{pH}$ of raw and cooked meat samples was measured using a digital pH meter Dzudie et al. [26] with some modifications. About $50 \mathrm{~g}$ of biceps femoris meat sample was homogenized with $30 \mathrm{ml}$ of prepared plant extracts individually for $4 \mathrm{hrs}$ at room temperature and then the $\mathrm{pH}$ value of marinated meat was measured before and after cooked at room temperature. The $\mathrm{pH}$ value of biceps femoris meat samples before cooked, after cooked and change in $\mathrm{pH}$ increment was significant $(\mathrm{p}=0.0000)$. From this finding the higher $\mathrm{pH}$ increment was observed in zingbain $(0.7 \pm 0.012)$ after cooked it becomes the normal range of meat $\mathrm{pH}$. While the least $\mathrm{pH}$ increment was recorded from papain $(0.2 \pm 0.04)$ and bromelains $(0.23 \pm 0.04)$ this may be due to the approximate $\mathrm{pH}$ action around the normal range of the meat $\mathrm{pH}$ (Table 6).

Table 6: Assessment of volunteer customer's satisfaction.

\begin{tabular}{|c|c|c|c|c|c|c|}
\hline \multirow{2}{*}{ Experimental Group } & \multicolumn{5}{|c|}{ Satisfaction Level of Meat Consumers } \\
\cline { 2 - 7 } & Highly liked N (\%) & $\begin{array}{c}\text { Moderately liked N } \\
\text { (\%) }\end{array}$ & $\begin{array}{c}\text { Liked N } \\
(\%)\end{array}$ & $\begin{array}{c}\text { Neither nor N } \\
\text { (\%) }\end{array}$ & $\begin{array}{c}\text { Less satisfied N } \\
\text { (\%) }\end{array}$ & $\begin{array}{c}\text { Least satisfied } \\
\text { N (\%) }\end{array}$ \\
\hline Control & - & - & - & $1(5.26)$ & $10(52.63)$ & $8(42.11)$ \\
\hline Bromelain (30 ppm) & $12(63.16)$ & $4(21.05)$ & $2(10.53)$ & $1(5.26)$ & - & - \\
\hline Papain (30 ppm) & $14(73.68)$ & $2(10.53)$ & $2(10.53)$ & $1(5.26)$ & - & - \\
\hline Zingbain (30 ppm) & $9(47.37)$ & $5(26.32)$ & $5(26.32)$ & - & - & - \\
\hline
\end{tabular}

\section{Conclusion and Recommendations}

In the current study, all three plant extracts (papain, bromelain and zingbain) have great effectiveness of tenderizing the meat in old aged animals including quanta, both dry and fresh fish meat [27]. Papain and bromelain have better tenderization efficiency at a wider range of temperature, approximately neutral $\mathrm{pH}$ and better cooking yield compared to the control and zingbain, bromelain also have approximate cooking yield to the control and slight acidic condition was recorded by zingbain. Similarly, the physicochemical properties related to $\mathrm{pH}$, marinating time, cooking yield and sensory evaluation were determined by volunteer sensory panelist best in papain followed by bromelain. In addition, papain can stay stored for 48 hours while, bromelain and zingbain can stay for 72 hours with slime appearance. But the control shows color change within $24 \mathrm{hrs}$ and it became brown to black after $48 \mathrm{hrs}$. In conclusion, this product can be an input and solution for such problem and used in different form of applications (solution, powder, injection, spray and marinating). Further large-scale research should be done for better improvement and scalability of the products and plant extracts. 


\section{References}

1. Nollet LM (2012) Food biochemistry and food processing. John Wiley \& Sons.

2. Likar K, Jevšnik M (2006) Cold chain maintaining in food trade. Food control 17(2): 108-113.

3. Saranya S (2017) Effect of ginger oil on tenderization of spent goat meat. Indian Journal of Small Ruminants 23(1): 68-72.

4. Koohmaraie M, Geesink G (2006) Contribution of postmortem muscle biochemistry to the delivery of consistent meat quality with focus on the calpain system. Meat science 74(1): 34-43.

5. Kargiotou C (2011) Efficacies of soy sauce and wine base marinades for controlling spoilage of raw beef. Food Microbiology 28(1): 158-163.

6. Lomiwes D (2014) Small heat shock proteins and their role in meat tenderness: A review. Meat science 96(1): 26-40.

7. Chéret R (2007) Calpain and cathepsin activities in postmortem fish and meat muscles. Food Chemistry 101(4): 1474-1479.

8. Lee SH (2014) Mutations in calpastatin and $\mu$-calpain are associated with meat tenderness, flavor and juiciness in Hanwoo (Korean cattle): Molecular modeling of the effects of substitutions in the calpastatin $/ \mu$ calpain complex. Meat science 96(4): 1501-1508.

9. Gaur SS, Agrahari, Wadhwa N (2010) Purification of protease from Pseudomonas thermaerum GW1 isolated from poultry waste site. The open microbiology journal 4: 67-74.

10. Adulyatham P, Owusu AR (2005) Stabilization and partial purification of a protease from ginger rhizome (Zingiber offinale Roscoe). Journal of food science 70(3): C231-C234

11. Ashie I, Sorensen T, Nielsen PM (2002) Effects of papain and a microbial enzyme on meat proteins and beef tenderness. Journal of food science 67(6): 2138-2142.

12. Wada M (2002) The effects of pressure treatments with kiwi fruit protease on adult cattle semitendinosus muscle. Food Chemistry 78(2): 167-171

13. Naveena B, Mendiratta S (2001) Tenderisation of spent hen meat using ginger extract. British poultry science 42(3): 344-349.

14. Pawar VD, Mule BD, Machewad G (2007) Effect of marination with ginger rhizome extract on properties of raw and cooked chevon. Journal of Muscle Foods 18(4): 349-369.
15. Jayasooriya SD (2007) Effect of high-power ultrasound and ageing on the physical properties of bovine Semitendinosus and Longissimus muscles. Meat Science 75(4): 628-639.

16. Sullivan GA, Calkins CR (2010) Application of exogenous enzymes to beef muscle of high and low-connective tissue. Meat science 85(4): 730-734.

17. Chen XL (2007) A novel type of subtilase from the psychrotolerant bacterium Pseudoalteromonas sp. SM9913: catalytic and structural properties of deseasin MCP-01. Microbiology 153(7): 2116-2125.

18. Koohmaraie M (1994) Muscle proteinases and meat aging. Meat science 36(1-2): 93-104.

19. Han J (2009) Pre-rigor infusion with kiwifruit juice improves lamb tenderness. Meat Science 82(3): 324-330.

20. Botsoglou N (2002) The effect of dietary oregano essential oil on lipid oxidation in raw and cooked chicken during refrigerated storage. Meat science 62(2): 259-265.

21. Naveena BS, Mendiratta SK, Anjaneyulu A (2004) Tenderization of buffalo meat using plant proteases from Cucumis trigonus Roxb (Kachri) and Zingiber officinale roscoe (Ginger rhizome). Meat Science 68(3): 363-369.

22. Calkins CR, Sullivan G (2007) Adding enzymes to improve beef tenderness. Beef Facts Product Enhancement. National Cattleman's Beef Association. Centennial Colorado: Cattlemen's Beef Board.

23. Ha M (2012) Characterisation of commercial papain, bromelain actinidin and zingibain protease preparations and their activities toward meat proteins. Food Chemistry 134(1): 95-105.

24. Takahashi K (1996) Structural weakening of skeletal muscle tissue during post-mortem ageing of meat: the non-enzymatic mechanism of meat tenderization. Meat science 43: 67-80.

25. Ketnawa S, Rawdkuen S (2011) Application of bromelain extract for muscle foods tenderization. Food and Nutrition Sciences 2(5): 393401.

26. Dzudie T, Ndjouenkeu R, Okubanjo A (2000) Effect of cooking methods and rigor state on the composition, tenderness and eating quality of cured goat loins. Journal of Food Engineering 44(3): 149-153.

27. Hashim MM (2011) Ginger rhizome as a potential source of milk coagulating cysteine protease. Phytochemistry 72(6): 458-464.

Your next submission with Juniper Publishers will reach you the below assets

- Quality Editorial service

- Swift Peer Review

- Reprints availability

- E-prints Service

- Manuscript Podcast for convenient understanding

- Global attainment for your research

- Manuscript accessibility in different formats

( Pdf, E-pub, Full Text, Audio)

- Unceasing customer service

Track the below URL for one-step submission https://juniperpublishers.com/online-submission.php 